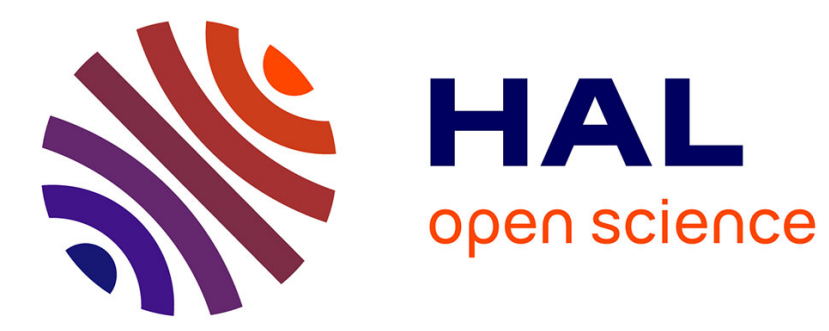

\title{
Nutritional ecology of herbivorous livestock in Gobi desert
}

A Miyazaki, Y Kojima, J Ishida, M Kitagawa, K Ushida, K Miyazaki, R Tserenduram, D Namsrai, C Renchinmyadag, D Batmunkh

\section{To cite this version:}

A Miyazaki, Y Kojima, J Ishida, M Kitagawa, K Ushida, et al.. Nutritional ecology of herbivorous livestock in Gobi desert. Annales de zootechnie, 1995, 44 (Suppl1), pp.345-345. hal-00889502

\section{HAL Id: hal-00889502 https://hal.science/hal-00889502}

Submitted on 1 Jan 1995

HAL is a multi-disciplinary open access archive for the deposit and dissemination of scientific research documents, whether they are published or not. The documents may come from teaching and research institutions in France or abroad, or from public or private research centers.
L'archive ouverte pluridisciplinaire HAL, est destinée au dépôt et à la diffusion de documents scientifiques de niveau recherche, publiés ou non, émanant des établissements d'enseignement et de recherche français ou étrangers, des laboratoires publics ou privés. 


\title{
Nutritional ecology of herbivorous livestock in Gobi desert
}

\author{
A Miyazaki 1, Y Kojima 2, J Ishida 1, M Kitagawa 1, K Ushida 2, K Miyazaki 2, \\ R Tserenduram 3, D Namsrai 4, C Renchinmyadag 4, D Batmunkh 4 \\ 'Laboratory of Animal Resources, Kyoto University, Kyoto 606-01; 2Laboratory of Animal Science, Kyoto \\ Prefectural University, Shimogamo, Kyoto 606, Japan; ${ }^{3 M o n g o l i a n ~ A c a d e m y ~ o f ~ S c i e n c e, ~ U l a n b a t o r ; ~}{ }^{4}$ Research \\ Institute of Pastoral Animal Husbundry in Gobian Zone, Bulgan Sum, Umnuugobi Aimag, Mongolia
}

Major livestock held in Gobi region in Mongolia are camels, sheep, goat, cattle, yaks and horses. These animals are kept under different management according to the purposes and their capacity of adaptation to the grazing condition. In those regions, livestock represent the major sources of human income. The knowledge about nutritional limitation of traditional grazing system is important to improve livestock production. This study was conducted to know the nutritive values and chemical composition of gobian plant consumed by the four major livestock, camel, sheep, goat and cattle.

Plants were collected in the Gobi desert regions around Bulgan, Umnuugobi province in February, April, July and October 1992 and February 1993 . The plants belonging to 6 families (Graminaes, Chenopodiaceae, Asteraceae, Polygalaceae, Leguminosae, and Iridaceae), 13 genera and 23 species were collected. Caution was taken to sample the part of plants actually grazed by the animals. The name of animals that grazed the particular plants were recorded. Proximate and detergent analysis were done on these plant samples. Mineral contents were measured. In situ DM digestibilities of these samples were determined by the nylon bag technique $(48 \mathrm{~h}$ incubation within $100 \mu \mathrm{m}$-pore nylon bags) using a ruminally fistulated cattle held in Kyoto Prefectural University.

Plants consumed by gobian livestock were different according to the animal: Camels and sheep consumed mainly Chenopodiaceae, the plants belonging to this family represent $60 \%$ or $40 \%$ of plants selected by camels and sheep, respectively. Goats consumed Graminaes (40\%) and Leguminosae (30\%), and cattle mainly consumed Graminaes $(60 \%)$. The ratios of Dicots to Monocots in the feed of camels, sheep, goats and cattle were respectively $4.5,2.1,1.5$ and 0.3 . The difference in type of plant consumed by these animals appeared to depend on the geographical separation of the animals : Camels and sheep were held on low land, but camels were kept in the salt-rich fields. Goat and cattle were held on the hill-side of northern part of Altai Mountains. Dietary overlaps were high between camels and sheep (36\%). No dietary overlaps was observed between lowland and hill-side animals.

Higher crude fibre contents and lower crude protein contents were generally detected in plants consumed by goats and cattle. The concentration of $\mathrm{Ca}, \mathrm{Mg}, \mathrm{Na}, \mathrm{K}$, and $\mathrm{P}$ were superior to the critical levels. However, $\mathrm{Zn}$ and $\mathrm{Cu}$ concentrations in the samples were lower than the critical levels. Fe concentration in the most plant grazed by sheep was superior to the toxic level and may affect Cu-utilisation in this animal.

Seasonal variations in potential digestibility (insitu digestibility) of plants samples were large in particular for the plants grazed by camel and sheep ; $80 \%$ in summer season samples and $30 \%$ or less in winter season samples. Such variations in digestibility were relatively small in the plants grazed by cattle and goats. 